Kaliopa DIMITROVSKA ANDREWS

\title{
Oblikovalska merila pri urejanju mest in drugih naselij
}

\section{Uvod}

Delovni osnutek Zakona o urejanju prostora in graditvi (november 1993) opredeljuje prostorske vidike kot sestavine prostorske strukture, ki zagotavljajo njeno skladnost in učinkovitost (čl.1.2.1/3 - temeljni pojmi), definira pa jih kot: razvojno (organizacijsko)-funkcionalne, varovalne in oblikovalske. Iz osnutka zakona je razvidno, da oblikovalski prostorski vidiki temeljijo na splošnih načelih estetike in spoštovanju kulturno-zgodovinskega izročila. (čl.1.2.1/3.3).

Splošna načela estetike so definirana kot "... sklop principov na podlagi dobrega okusa in spoštovanja lepote" (The Concise Oxford Dictionary, str. 17). Prav zato je, preden preidemo na definiranje oblikovalskih meril, pomembno, da najprej pojasnimo vlogo estetike $\mathrm{v}$ zgodovini planiranja in načrtovanja mesta ter analiziramo oblikovalska določila $\mathrm{v}$ sodobnih predpisih o planiranju in urejanju prostora (v zahodnoeviopskih državah), predvsem $\mathrm{z}$ vidika spoštovanja (varovanja in razvoja) naravnih in kulturnozgodovinskih danosti oziroma značilnosti prostora.

\section{Vloga oblikovanja in/ali estetike v zgodovini planiranja in načrtovanja mest}

Oblikovanje in estetika sta opredeljena kot dve sestavini istega procesa, in sicer, oblikovanje kot aktivnost pri organizaciji oblik in prostorov ter estetika kot vizualna presoja končnega izdelka.

Poenostavljena razprava o estetskem doživljanju urbanega okolja (gl. Dimitrovska, 1993) identificira dva osnovna tipa reakcije na obliko grajenih form:

1. senzualno reakcijo (formalno, Santayana - gl. Lang 1987; prirojena estetska senzibilnost, Smith, 1987), ki temelji na prirojeni sposobnosti človeka, da zazna in odgovori na določeno stopnjo elegance $v$ grajenem okolju, kot so pravilne oblike, simetrične forme, forme v proporcu;

2. intelektualno reakcijo (simbolno, Santayana), pri kateri je reakcija rezultat intelektualnega zaznavanja in razumevanja okolja, oziroma pri kateri je vrednotenje vizualne pojavnosti, funkcije in pomena urbanega okolja in objektov rezultat predhodnega znanja in izkušenj posameznika, vključno s socioekonomskimi in kulturološkimi vplivi.

V okviru planiranja izraz estetski večinoma uporabljamo zato, da bi izrazili vizualno-oblikovni rezultat razvoja, saj ima večina objektov v arhitekturni in urbanistični praksi empirično, fizično naravo, ki je zaznavna predvsem vizualno.

Estetska presoja izhaja pretežno iz ocene vidljivega, ocene povišja in zunanjosti. Dominacija vizualne percepcije je odvisna od senzualnega ogrodja, ki uravnava sam akt gledanja oziroma načine opazovanja. To ogrodje je lahko kulturološko, ideološko, včasih tudi politično. Kaj bomo videli, kako, s kakšnega zornega kota in s kakšnim namenom, je že vnaprej določeno $z$ uporabo določenih "pravil gledanja" (Teymur, 1981, str. 82-83).

$Z$ clrugimi besedami, senzualna, percepcijska ocena, ki je sicer $\mathrm{v}$ filozofskem smislu subjektivna in relativna, je zelo pogosto družbeno in historično determinirana.

Estetska dimenzija grajenih oblik ne more biti reducirana samo na oceno njihove pojavnosti ali vizual-
Estetska presoja Urbanističnooblikovalska merila Urbanistično oblikovanje $v$ okviru planiranja

Estetska presoja je opredeljena kot proces s katerim se upliva na aktivnosti pri organiziranju oblik in na vizualno presojo končnega proizvoda. Po zgodovinskem prikazu vloge estetske presoje prioblikovanjumest ter njene vmeščenostiv sodobne planerske procese so predstavljeni primeri kodifikacije $v$ področni zakonodaji različnih evropskih držav, vključno s Slovenijo. Posebej so izpostavljena urbanističnooblikovalska merila. V zvezi z veckcrat izrečeno pripombo, da je $v$ praksi skoraj nemogoče proizvesti estetskega okolja je $v$ zaključku predlog priprave priročnika za oblikovanje urbanih prostorov.

Kaliopa Dimitrouska Andrews Aesthetic criteria for planning urban and other settlements

Aesthetic assesment Urban design criteria Urban design and the system of planning

Aesthetic assessment is defined as a process by which activities in organising shapes and visual evaluation of the final product are influenced. A historic survey of the scope and role of aesthetic assessment in town design is followed by a comparison of the placement of aesthetic assessment in the laws of particular European countries including Slovenia. Urban design criteria are especially elaborated. As a result of the often heard remark, that it is almost impossible to produce an aesthetic environment, a proposal for a manual on the design of urban spaces is presented. 
nih razsežnosti, ne da bi upoštevala tudi socialne, ekonomske in kulturne okoliščine, $v$ katerih so bili te oblike zgradili, distribuirali in uporabljali.

Skratka, glavne značilnosti estetske presoje grajenega okolja so:

1. usmerjena je $\mathrm{v}$ vizualno percepcijo in oceno zunanjosti;

2. gre za izkustveno, subjektivno in emocionalno razumevanje grajenega okolja in njegovih metaforičnih in simboličnih razsežnosti;

3. estetsko "znanje" je v arhitektonskem in urbanističnem pogledu vsota intuitivnih, profesionalnih, ideoloških in izkustvenih informacij, ki vključujejo tudi sociozgodovinske in tehnološke vidike.

Zaščita vizualnih lastnosti pri grajenih formah je bila prisotna $\mathrm{v}$ oblikovanju grških in rimskih mest in še prej. Znani so Aristotelovi principi lepote in varnosti $\mathrm{v}$ mestu, Vitruvijevi napotki o zasnovi mesta, Albertijeve renesančne ideje o idealnih oblikah ulic in trgov (različnost in enotnost). Čeprav so bili prvi primeri estetskega nadzora predvsem rezultat zasebnih interesov (npr. kralja, aristokracije, cerkve), bolj značilni primeri izhajajo šele iz obdobja od 12. do 14. stoletja, ko so bile osnovane različne mestne komisije, da bi nadzorovale urbanistični razvoj v samostojnih, svobodnih mestih ali mestnih držav (toscanska mesta, Zürich, Bern, Benetke, Dubrovnik). Tako je, na primer, v mestnih arhivih v Sieni, ohranjeno na stotine različnih predpisov, uredb in napotkov oziroma navodil za planiranje, oblikovanje in financiranje ulic, trgov, cerkva, vodnjakov, vhodov $\mathrm{v}$ mesto oziroma mestnih vrat in podobno, ki so bili namenjeni pooblaščenim komisijam in arhitektom.

Mestni zakonodajalci so posvečali veliko pozornost zlasti uniformiranemu razvoju glavnih ulic: določanje in zaščita ulične linije, uporaba homogenih gradbenih materijalov, enotno oblikovanje pritličja objektov. Podobno so pri oblikovanju mestne podobe Berna uporabili natančno opredeljena gradbena pravila (codes). Zaradi izpeljane regulacije vrstnih hiš "čistih" fasad in enotno arkadiranih pritličij velja Bern še danes za eno od najlepših evrospkih mest. Toda to, kar je predvsem zanimivo pri mestih kot so Bern, Siena in ostala srednjeveška mesta, je dejstvo, da so enaka pravila pri gradnji uporabljali nekaj stoletij (od 13. do 19. stoletja), kar je omogočalo "renoviranje fasad skladno s časom, primernim okusom oziroma modo, vendar tako, da so proporci ostajali še vedno enaki" (Braunfels, 1988, str.76).

$\mathrm{V}$ obdobju po renesansi je veliko mest skušalo zelo natančno upodobiti svoj fizični videz. Arhitektonski profil mesta in prikaz njegove silhuete je postal pomemben element ugleda mesta in obenem reklama za njegovo veličastnost. Tako obstajajo izredno lepi pogledi na mesta, kot so Firence, Benetke (1500), Antwerpen (1515), Nürnberg, Frankfurt, Lubeck (1552) (Braunfels, 1988). Vsako mesto se je želelo predstaviti kot "kompletno, jasno arhitektonsko zasnovano in dokončano, varno, hualevredno, vedro in brezbrižno" (Braunfels, 1988).

Fanatično hrepenenje renesančnega mesta po redu v mestni kompoziciji in podobi je oblikovalo lirične estetske elemente, ki so imeli vse do danes močan vpliv na sodobno planiranje mesta. Sitte (18431903), ki ga nekateri imenujejo "oče modernega planiranja mesta”, je poenotil oziroma združil Aristotelove principe pri oblikovanju mesta ("napravi, da se ljudje počutijo varne in srečne"), Vitruvijeva priporočila o zasnovi mesta in Albertijeve renesančne ideje o idealnih oblikah ulic in trgov $\mathrm{v}$ temeljne principe mestnega oblikovanja (the art of building cities). Sittejeve ideje o uporabi estetike $\mathrm{v}$ procesu planiranja so povzete $\mathrm{v}$ izvlečku manifesta, ki ga je 1 . 1877 objavilo Društvo avstrijskih inženirjev in arhitektov:

"Oblikovanje mesta $v$ celoti, kot tudi njegovih posameznih delov, je pomembno umetniško dejanje. Načrti mesta in mestne rasti niso samo dejanje ravnil in šestil, ampak sokot artistična naloga-tukaj potrebne najprej ideje in potem globoko razumevanje potreb metropole 
ter zahteve modemega načina življenja, še bolj pa senzualen občutek oblikovanja prostora in razumevanje oblik."

Sitte si je prizadeval za uporabo tridimenzionalnega mestnega plana (Bebaungsplan), ki so ga začeli uporabljati po letu 1890. Pozneje je postal osnova za podrobnejšo gradbeno regulacijo, še posebej za coning višin. Coning je bil pravzaprav nemška iznajdba, definiran pa je kot: "neobhodni mehanizem za vzdrževanje določenega reda in sredstvo za zašcito jaunega interesa med nenadzorovanim razvojem mest in sproščene špekulacije $z$ zemljišč - preprosta potreba $v$ obdobju zgodnjega planiranja mesta" (Collins, 1972, str. 27).

Sitte je imel velik vpliv v Avstriji in Nemčiji. Številne občine so predelale svoje mestne načrte na podlagi Sittejevih teoretskih napotkov (npr. Linz, Brno) ali pa po navodilih njegovih učencev, naslednikov, kot sta Henrici (Dessau) in Fisher (München). To obdobje močnega estetsko-arhitektonskega vpliva pri planiranju mest v Nemčiji (konec 19. stoletja), znano kot "romantično obdobje", se je razširilo tudi v druge evropske dežele in Ameriko. Belgijec Charles Buls v knjigi Estetika mesta (1893) odobrava Sittejeva določila o urbani estetiki. V ZDA so v okviru gibanja City Beautiful (Lepo mesto), ki so ga ustanovili med svetovno razstavo leta 1893 , uspeli $\mathrm{v}$ planiranje mest vključiti tudi principe lepih umetnosti o kompoziciji, simetriji in oblikovnem poudarku.

V začetku 20. stoletja so poskušali Wagner, Muthesius, Hegemann in ostali prilagoditi teorijo o lepoti in funkciji sodobnim potrebam planiranja mesta. Ker se je sodobno planiranje razširilo na regijo in na proučevanje regionalne climenzije urbanega nukleusa, je mesto začelo izgubljati svojo pomembnost. V tem času zasledimo samo priporočila o silhueti in postavitvi mesta v naravni krajini ter napotke o oblikovanju grajenih robov oziroma meje, kjer se stikata urbano in naravno okolje. V tem obdobju je pomembna angleška ideja vrtnega mesta, ki se je v nekoliko poenostavljeni obliki razširila po vsej Evropi. Tako so v Avstriji in
Nemčiji idejo vrtnega mesta poenotili $\mathrm{z}$ oblikovanjem mestnih predmestij (Anlagen na Dunaju) in delavskih naselij ("nova mesta" za delavce $v$ tovarni Krupp $v$ Nemčiji), ne pa $\mathrm{V}$ celoti $\mathrm{z}$ novim pojmovanjem Življenja. V Franciji je Howardova ideja vrtnega mesta doživela močno podporo (Združenje vrtnih mest $\mathrm{v}$ Franciji), toda omejili so jo predvsem na načrtovanje primestnega urbanega razvoja. Planiranje mest $v$ Franciji je bilo tedaj še vedno pod močnim vplivom rekonstrukcije in transformacije Haussmannovega Pariza.

\section{Oblikovalski vidliki $\mathrm{v}$ sodobni planerski praksi}

Za obdobje planske nadzora po II. svetovni vojni je značilno, da je zahtevalo kompleksnejši, celovitejši nadzor, zato je imelo estetsko nadzorovanje manj pomembno vlogo. $\mathrm{V}$ Evropi so se v 50. letih urbanisti in prostorski planerji ukvarjali s problemi hitre urbanizacije, zasnovo rabe površin in organizacijo dejavnosti, predvsem pa $\mathrm{z}$ urejanjem močno naraščajočega prometa (Planning Control). Planski načrti so bili tedaj v obliki "grandioznih, dolgoročnih planov namenske rabe, ki so prekrivali skoraj celotno območje države, brez kakršnihkoli določitev o tem, kako naj bi jih realizirali" (Ravetz, 1986). Te plane pa je bilo predvsem težko redno vzdrževati in jih prilagajati nastalim spremembam ter zahtevam razvoja (Cullingworth, 1982). Zato so jih $\mathrm{v}$ poznih 60. letih začeli opuščati, vseobsežno planiranje pa so začeli nadomeščati $z$ bolj poenostavljeno plansko dokumentacijo, ki naj bi se bolj prilagajala dejanskim potrebam $\mathrm{v}$ prostoru. V Angliji so v planerski praksi uspeli razviti sistem, za katerega sta značilna fleksibilnost in administrativna diskrecija, ki omogočata relativno hitro in enostavno uveljavljanje nastalih sprememb $\mathrm{v}$ planiranju razvoja. V 70. letih se je interes urbanistov začel ponovno usmerjati k urejanju problemov na pretežno zgrajenih območjih, k rekonstrukciji, revitalizaciji in rehabilitaciji mestnih središč. Tako je prišlo znova do reafirmacije oblikovne dimenzije planiranja. V večini 
dry̆av so posamezne oblikovalske elemente oziroma elemente estetskega nadzora vgradili $\mathrm{v}$ veljavno zakonodajo o prostorskem planiranju. Predhodna analiza teh sistemov kaže na to, da za izvajanje estetskega nadzora ali nadzora oblikovanja $\mathrm{V}$ praksi uporabljajo številne druge neformalne dokumente in postopke, kot so oblikovalske strategije in smernice za posamezna mesta (npr. Birmingham, San Francisco, Portland), oblikovalski priročniki ali vodniki za določena področja oblikovanja (design guide), oblikovalski programi in usmeritve za določene lokacije (design briefs), revizija oblikovanja (ZDA, Anglija, Nizozemska) in podobno.

\section{Oblikovalski elementi v predpisih o planiranju in ' urejanju prostora v državah zahodne Evrope}

V Avstriji je v Občinskem zakonu o planiranju (Gemeinderplanungsgesetz, 1970), ki določa vsebino plana namenske rabe prostora in postopek njegovega sprejemanja, določena tudi vloga, vsebina in postopek pri sprejemanju zazidalnega načrta. Kot enega od možnih inštrumentov nadzora planiranja pa predvideva tudi načrt oblikovanja (Gestaltungsplan). Ta načrt oblikovanja praviloma določa tudi ukrepe za ohranitev in oblikovanje značilnih mestnih in krajevnih jeder, npr. oblike streh, kritine, arhitekturne elemente in barve (Prelovšek, 1988).

Na Danskem vsebuje estetski vidik gradnje Zakon o občinskem planiranju, ki dopušča, da lokalni plan vsebuje določbe glede zunanjega izgleda stavb (po Ogorelec, str. 48).

V Franciji Zakon o urbanizmu (Code de l'urbanisme et de l'habitation, 1977) dovoljuje izdajo dovoljenja za gradnjo le takrat, kadar je načrtovana stavba $v$ skladu $\mathrm{z}$ zakonskimi odredbami in predpisi, ki se nanašajo tudi na lego, velikost in zunanji izgled stavbe (po Ogorelec, str. 49).

Zazidalni načrt v Nemčiji (Zvezni zakon, Baugesetzbuch, 1986) določa elemente urbanističnega oblikova- nja, kot so način zazidave, lega in višina stavb, oblike nezazidanih površin.

Na Nizozemskem je z zazidalnim načrtom (Bestemmingsplan) določen volumen in lokacija stavbe. Pred izdajo gradbenega dovoljenja si pooblaščena oseba največkrat pridobi mnenje estetske komisije, ki jo sestavljajo lokalni arhitekti in drugi strokovnjaki (po Ogorelec, str. 4950).

V Angliji zahteva dopolnjena zakonodaja (Planning Policy Guidance Note No. 1, DoE, 1992), da oblikovalsko dimenzijo upoštevajo pri izdaji dovoljenja za urejanje prostora oziroma lokacijskega dovoljenja, ne vsebuje pa podrobnih navodil, kako naj lokalne oblasti to izvajajo, oziroma katere oblike nadzora so bolj zaželene: formuliranje oblikovalske politike $v$ lokalnih planih, priprava suplementarne dokumentacije, kot so oblikovalski vodniki in programi (design guides and briefs), ali pa izvajanje estetske presoje $\mathrm{v}$ procesu planskega nadzora (arhitekturni paneli, kot na primer na Nizozemskem). V Angliji upoštevajo esteski vidik, ki praviloma obravnava oblikovanje objekta, zunanji izgled in njegovo razmerje do okolice, kot eno od meril pri presoji za izdajo dovoljenja.

Povzamemo lahko, da skoraj v vseh navedenih državah vsebujejo predpisi o urejanju prostora tudi oblikovalske vidike, ki se nanašajo predvsem na: ohranjanje in negovanje podobe kraja, značilnih mestnih predelov in krajevnih jeder (Avstrija, Francija, Nemčija, Anglija), lego, velikost/volumen in $\mathrm{zu}$ nanji izgled stavbe ter na arhitekturne elemente, kot so oblika strehe in vista kritine, stavbne mase in členitev, barve in materiali, torej, vse kar določa zahteve po skladnosti z okolico.

\section{Oblikovanje v okviru planiranja in načrtovanja prostora v Sloveniji}

Oblikovanje $\mathrm{v}$ slovenskem planerskem sistemu (prostorska zakonodaja iz leta 1984) se nanaša pretežno na določila o urbani in arhitek- 
turni kontinuiteti razvoja naselij ter na določila o upoštevanju konceptov dejanske tlorisne zasnove naselij glede oblikovanja stavbnih mas, uporabe arhitekturnih prvin, materialov in načinov obdelave fasad. Lahko bi rekli, da predpisi o oblikovanju temeljijo na kvalitativnih merilih, kot so: kompatibilnost, harmonija, identiteta, pomen prostora, prijetnost ambienta, dostopnost, nanašajo pa se na "javno" podobo kraja oziroma na oblikovanje javnih površin, kot so ceste, ulice, trgi.

Zakon o urejanju prostora (čl. 24, 1984) zahteva, da urbanistična zasnova naselja, ki je sestavni del dolgoročnega plana občine, vsebuje tudi opredelitve za uresničevanje urbanistične oziroma krajinske zasnove $z$ urbanistično-oblikovalskimi ușmeritvami za urejanje posameznih območij ali naselij in usmeritvami za varovanje naravne in kulturne dediščine ter ostalih krajinskih vrednot. Poleg tega, zakon v 34 . in 43. členu zahteva, da urbanistična zasnova določa zaokrožene prostorske in funkcionalne celote $z$ usmeritvami za njihovo urbanistično urejanje, v srednjeročnem planu za območja, za katera bodo izdelani prostorski izvedbeni načrti, pa bi morali določiti pogoje za urbanistično, arhitektonsko in krajinsko oblikovanje.

Zakon o urejanju naselij in drugih posegov v prostor (čl. 9, 30, 31, 40, 1984) zahteva:

1. ohranitev in razvoj urbanega in arhitekturnega kontinuuma, pri katerem je razvoj naselja v skaldu s krajinskimi značilnostimi, z naravno in kulturno dediščino, s tipologijo regionalne arhitekture in $z$ drugimi naravnimi in $z$ delom pridobljenimi vrednotami $\mathrm{v}$ okolju. V Navodilih o vsebini posebnih strokovnih podlag in o vsebini prostorskih izvedbenih aktov (prostorskih ureditvenih pogojih, zazidalnih, ureditvenih in lokacijskih načrtih) (čl.15, 1985) je določeno, da morajo oblikovalski pogoji upoštevati: ekološke značilnosti, koncept stare tlorisne zasnove naselja in lokalne tradicije pri oblikovanju stavbnih mas, uporabi arhitektonskih prvin ter obdelavi fasad in uporabe materialov, prilagoditev novogradnje gabaritom obstoječih sosednjih objektov in naprav ter gradbeni crti, ohranitev obsega in členjenosti vișoke vegetacije ter uporabo predvsem krajevno značilnih rastlinskih vrst pri novih zazidavah (zasaditvah), optimalno ohranjanje oziroma vzpostavljanje naravnega značaja površinskih voda in naravnega reliefa;

2. določitev pogojev za oblikovalske rešitve območja in oblikovalske rešitve objektov in naprav v sklopu zazidalnega oziroma ureditvenega načrta. V Navodilih o vsebini posebnih strokovnih podlag in o vsebini prostorskih izvedbenih aktov (čl. 25 in 26) je podrobneje obclelana vsebina teh clokumentov, ki določa "razporeditev objektov, velikost objektov in površin odprtih prostorov, javne odprte prostore po namenu in zelene površine $z$ njihovo ureditvijo, dopustne višine, usmeritve za oblikovanje $z$ največimi horizontalnimi gabariti in najmanjšimi možnimi odmiki od objektov in od javnih površin, ter oblikovanje fasad, smeri glavnih dostopov in dovozov ter usmeritve za ureditev okolice";

3. določitev pogojev za urbanistično oblikovanje območja in arhitektonsko oblikovanje objektov $\mathrm{v}$ odloku o prostorskih ureditvenih pogojih, zazidalnem, ureditvenem ali lokacijskem načrtu.

Zakon zahteva (čl. 55), da za območja, ki se urejajo s prostorskimi ureditvenimi pogoji, pred izdajo dovoljenja, izdelamo lokacijsko dokumentacijo, ki vsebuje podatke o oblikovanju objektov in naprav, in sicer podatke o legi, obliki, velikosti in višini objektov ter podatke o javnih površinah in njihovi opremi. Takšno lokacijsko dovoljenje (čl.54) je v skladu $z$ urbanističnimi, oblikovalskimi in ureditvenimi pogoji, ki jih določa lokacijska dokumentacija.

$\mathrm{V}$ zvezi $z$ navedenim lahko sklepamo, da je oblikovanje pomembna sestavina $\mathrm{v}$ sistemu planiranja in načrtovanja prostora $\mathrm{v}$ Sloveniji skoraj na vseh ravineh, $\mathrm{v}$ prostorski 
zakonodaji pa so navedene podrobne zahteve glede oblikovalskih elementov, ki naj bi jih vsebovali urbanistični dokumenti. Toda večina pripomb strokovnjakov in laikov (Razmišljanja o Ljubljani, 1991) se nanašajo prav na kritiko urbanističnega oblikovanja oziroma podobe mesta in so estetskega značaja. Vzroki za takšne pomisleke so različni, od političnih do ekonomskih, pa tudi strokovnih:

1. Pomanjkljivosti v kontinuiteti oblikovanja oziroma oblikovalskih usmeritev med splošno-plansko in lokalno-izvedbeno ravnijo planiranja.

V zasnovi dolgoročnega razvoja mesta je določena ( $v$ večini planskih dokumentov) zasnova organizacije dejavnosti, zasnova namenske rabe v prostoru, določeno pa je tudi oblikovanje zaokroženih prostorskih in funkcionalnih celot mesta, ne da bi bila določena oblikovalska strategija $\mathrm{v}$ razvoju podobe mesta kot celote. Ta pomanjkljivost, ki je lahko rezultat površne razlage premalo poudarjenih določil zakona o kontinuiteti oblikovanja pri razvoju naselij, je tudi eden od razlogov za pomanjkljivosti $v$ oblikovanju fizičnih strukturv naših mestih, od dolgoročne planske zasnove do izvedbe.

2. Presplošne oblikovalske usmeritve $\mathrm{V}$ izvedbeni planski dokumentaciji.

Oblikovalske usmeritve, ki jih določa zakon, največkrat pa se nanašajo na določila o upoštevanju konceptov obstoječe tlorisne zasnove in podobe naselij oziroma njihovih območij (oblikovanja stavbnih mas, uporabe arhitekturnih prvin, materialov in načinov obdelave fasad), najpogosteje povzema tekstualni del izvedbene planske dokumentacije (glej analizo PUP-ov), ne da bi bile podrobneje ovrednotene glede na predhodno narejene analize fizičnih struktur in njihovih značilnosti v obravnavanem območju. Oblikovalska določila bi morala izhajati iz vnaprej pripravljenih strokovnih podlag (npr. oblikovalske usmeritve za razvoj karakterističnih mestnih območij) ali oblikovalskih vodnikov (npr. arhitekturne krajine).

3. Rutinski profesionalizem pri pripravi planske in izvedbene dokumentacije.

$\mathrm{V}$ novejši planerski praksi sicer zasledimo uporabo različnih metod in tehnik za določanje oblikovalskih izhodišč pri pripravi izvedbene urbanistične dokumentacije, kot so npr. percepcijski pristopi, urbanomorfološka analiza in metoda strukturne transformacije.

Njihova uporaba je odvisna od strokovne izbire posameznega izdelovalca/avtorja, saj ne obstaja določen sistematičen pristop $\mathrm{k}$ obravnavi oblikovalske problematike, ki bi bil primeren za hierarhično uporabo oziroma za uporabo na posameznih ravneh planiranja. Zato je treba $z$ uvedbo novih pristopov in tehnik izboljšati proces prostorskega in urbanističnega planiranja. Te bodo v zvezi $z$ razvojem mesta omogočile in kompleksno proučevanje urbanih form.

\section{Urbanistično oblikovalska merila}

Shirvani (1985) navaja tri osnovne kategorije oblikovalskih meril: merljiva, nemerljiva in splošna. Merljiva merila so uporabna pri oceni funkcionalnosti in učinkovitosti oblikovanja, kadar obravnavamo oblikovanje npr. kot tehnično (tehnološko) clisciplino. Nemerljiva merila, ki so v uporabi bolj kot ocena stališč oziroma meril neke določene skupine (umetniki, oblikovalci, planerji), so bolj uporabna $\mathrm{v}$ primeru, ko obravnavamo oblikovanje predvsem kot umetnost. Tretja skupina oblikovalskih meril, tako imenovani splošna ali dana merila, se je izoblikovala $\mathrm{v}$ planerski stroki 60. let, zasnovana pa je na socialnih merilih, ki so prav tako nemerljiva, in sicer enakosti, enakopravnosti in pravičnosti. V planerski in urbanističnooblikovalski praksi vedno obstajajo poskusi uporabe različnih kategorij meril in želja po njihovi uravnovešeni uporabi. V urbanističnooblikovalskem procesu bi morali po Shirvaniju upoštevati in 
obravnavati merljiva in nemerljiva merila v sklopu splošnih meril, ki naj bi tako uresničevala tudi etičnesocialne razsežnosti.

\section{Merljiva - kvantitativna merila}

Merljiva ali kvantitativna merila se lahko nanašajo na naravne dejavnike, kot je podnebje, sončna energija, urbana geologija, urbana hidrologija in podobno, in na fizične forme, kot so višina in obseg objektov, izraba, zazidanost, zamiki vertikalnih fasad. Upoštevanje naravnih dejavnikov je vsekakor zelo pomembna sestavina pri koncepciji zazidave in oblikovanja posameznih objektov in ureditev, vendar ga $\mathrm{v}$ tem prispevku ne obravnavamo podrobneje

Vsekakor se morata tako planer kot oblikovalec zavedati pomembnosti teh dejavnikov, saj bi se morala $v$ praksi konzultirati s strokovnjaki s teh področij. Druga skupina merljivih meril obravnava meritve tridimenzionalne pojavnosti urbanih form. Obstajata dva tipa meritev: konvencionalne in inovativne.

Najbolj pogosto uporabljene konvencionalne meritve so:

1. Izraba (FAR - floor area ratio; COS-coeficient d'occupation des sols; plot ratio), koeficient izrabe pomeni razmerje med celotno koristno površino objekta in površino parcele oziroma stavbnega zemljišča. Indeks izrabe stavbnega zemljišča tako izraža, koliko $\mathrm{m}^{2}$ bruto etažne površine (BEP) pride na vsak $\mathrm{m}^{2}$ pripadajočega stavbnega zemljišča (slika 1).

2. Zazidanost (site-coverage), koeficient zazidanosti izraža razmerje med zazidano površino objekta (stavbišče) in površino parcele (stavbnega zemljišča). Indeks zazidlanosti stavbnega zemljišča izraža, koliko $\mathrm{m}^{2}$ zazidane površine oziroma stavbišča pricle na vsak $\mathrm{m}^{2}$ pripadajočega stavbnega zemljišča.

3. Prostornost (stavbna masa), koeficient prostornosti izraža razmerje med volumnom stavbne

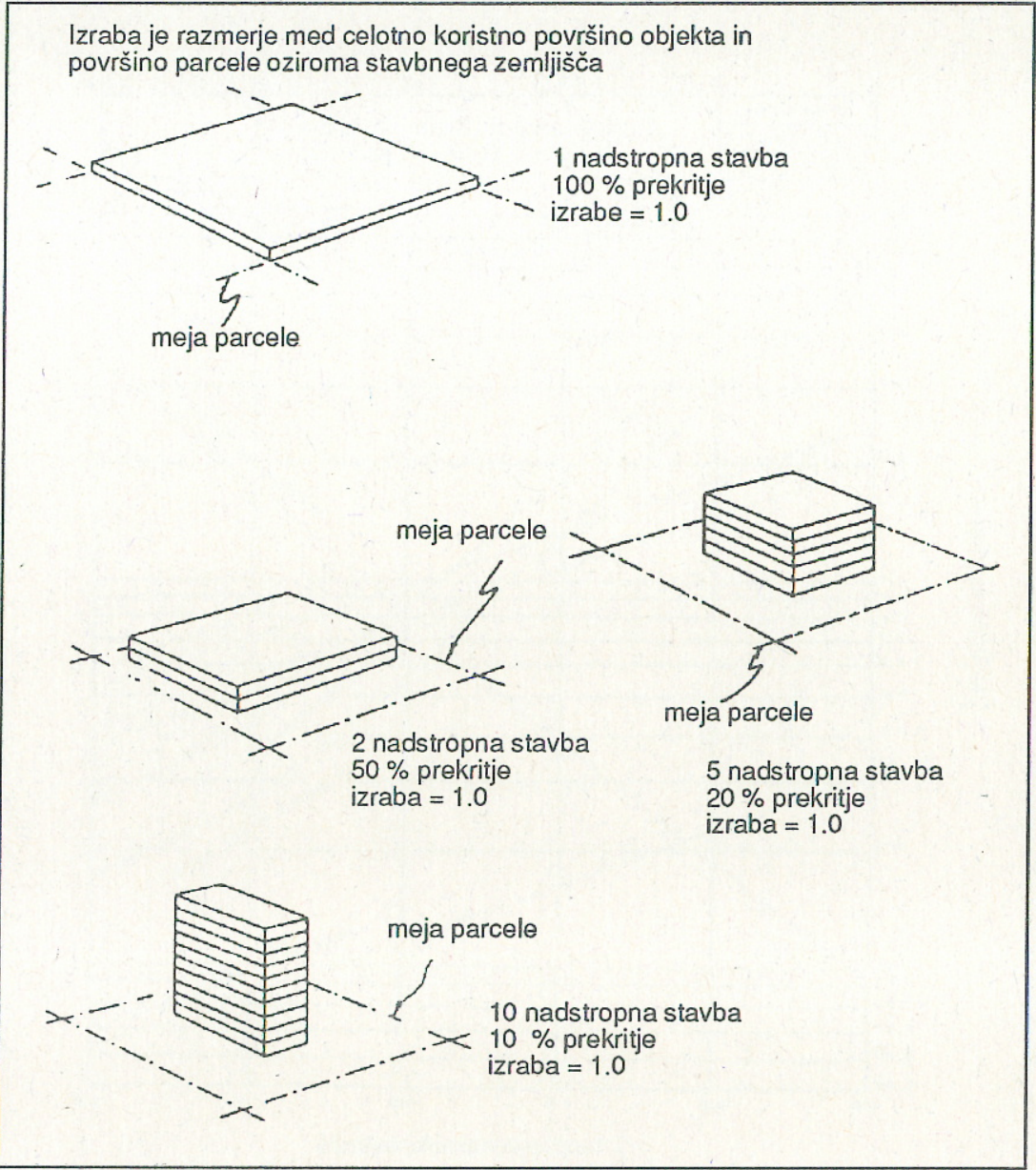

Slika 1: Izraba $(i=1)$

Vir: DeChiara \& Lee Koppelman, Urban Planning and Design Criteria, 1975
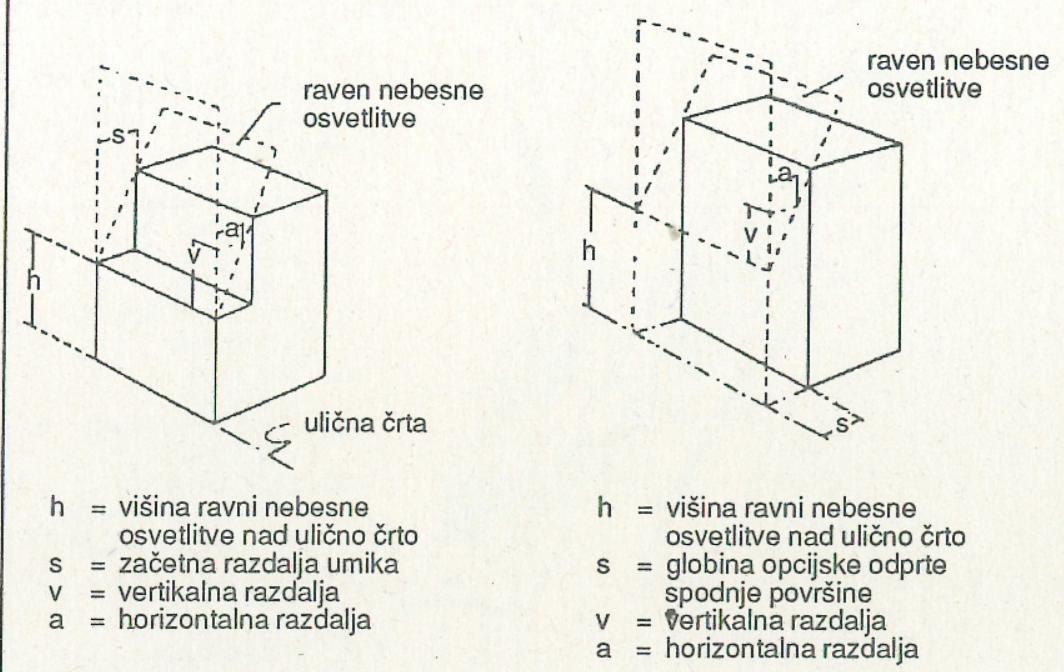
$\mathrm{h}$ = višina ravni nebesne osvetlitve nad ulično črto
$\mathrm{s}=$ začetna razdalja umika
$\mathrm{v}=$ vertikalna razdalja
$\mathrm{a}=$ horizontalna razdalja

Ilustracija ravni nebesne osvetlitve

$\mathrm{RNO}=$ vertikalna razdalja / horizontalna razdalja

Ilustraciia variacije RNO

$\mathrm{Na}$ ozkih ulicah bo naklon manjši kot na širokih.

Višina (h) mora biti vsklajena s splošnim merilom sosednih struktur.

Slika 2: Raven osvetlitve

'Vir: DeChiara \& Lee Koppelman, Urban Planning and Design Criteria, 1975 


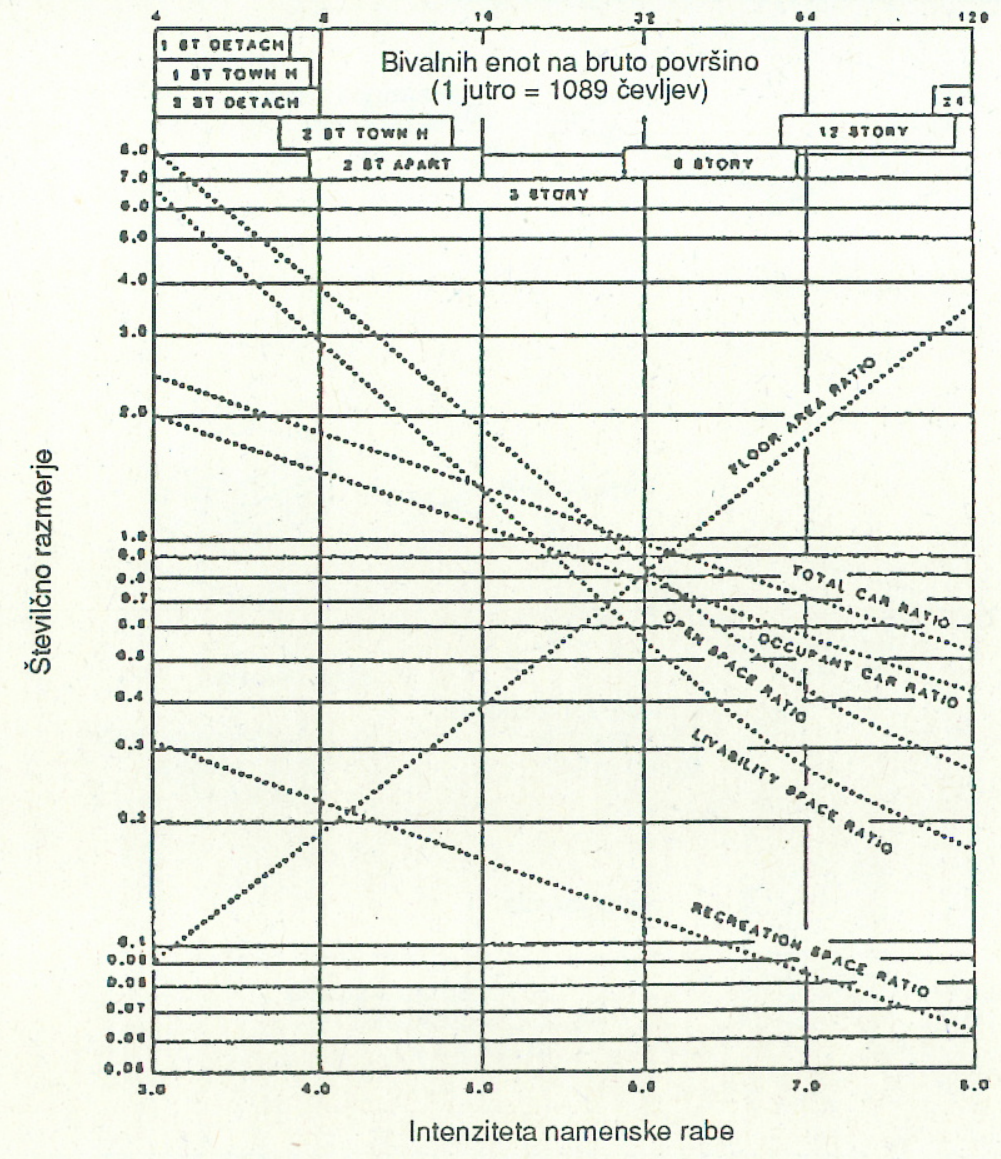

Slika 3: Intenziteta namenske rabe

Vir: Shirvani, The Urban Design Process, 1985

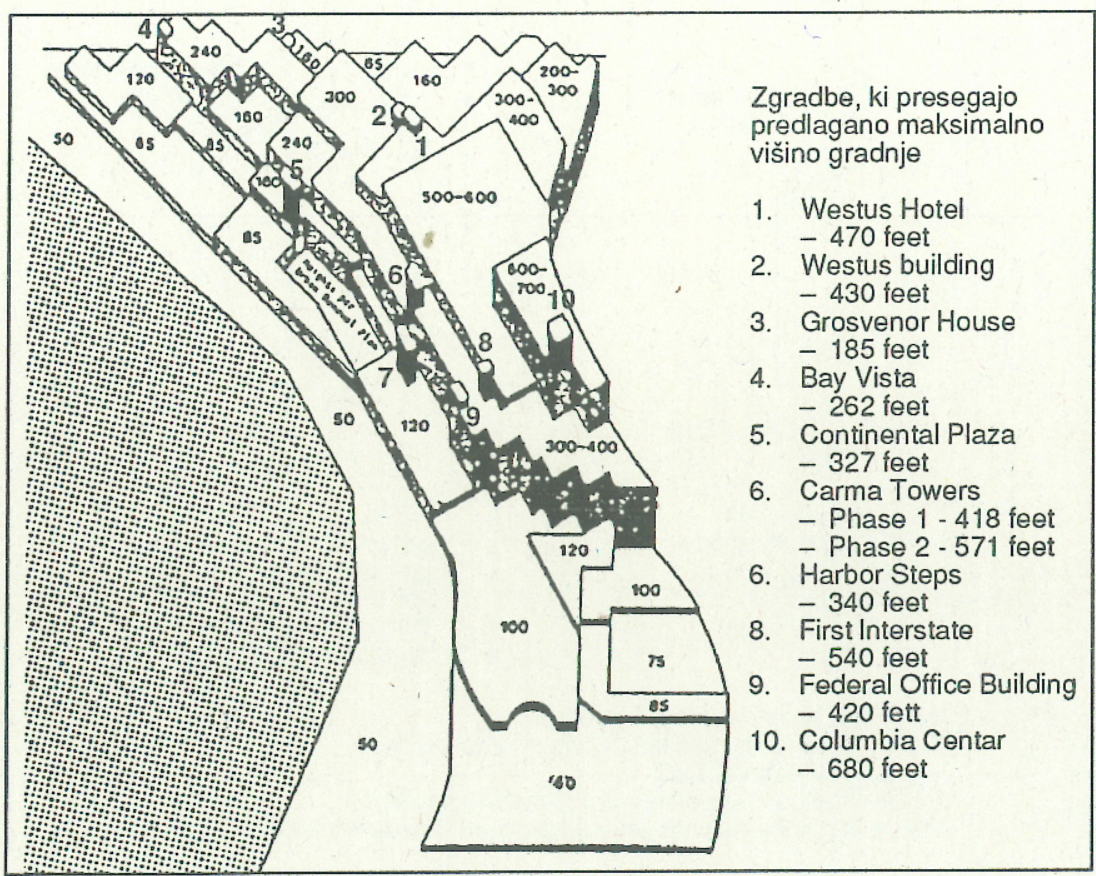

Slika 4: Koristna pouršina oleraja

Vir: Shirvani, The Urban Design Process, 1985 mase in površino parcele (stavbnega zemljišča). Indeks prostornosti (stavbne mase) izraža, koliko $\mathrm{m}^{3}$ stavbnega volumna pricle na vsak $\mathrm{m} 2$ pripadajočega stavbnega zemljišča.

4. Gostoto običajno računamo s številom oseb na ha ali stanovanjskih enot na ha (v Angliji število sob na ha).

5. Osončenje in osvetlitev - raven nebesne osvetlitve (sky exposure plane), projecirna ravnina, ki določa maksimalne višine objekta (zamiki čelne fasade), ki še omogočajo dobro osvetlitev nasprotnih objektov: razmerje med vertikalno razclaljo in horizontalno razdalji (v ZDA-ju uporabljajo predvsem v določilih "coning-a") (slika 2).

$\mathrm{V} Z \mathrm{ZDA}$ so $\mathrm{v} 60$. letih razvili nekatere inovativnejše metode, in sicer:

\section{Intenziteto namenske rabe (LUI} - land use intensity), numerični diagram, ki ga uporabljajo pri planiranju stanovanjskih sosesk za določanje potrebnih površin za sprejemljive dejavnosti (npr. promet, parkiranje, zelene površine, druženje stanovalcev/družbene dejavnosti) glede na tip izbrane stanovanjske zazidave (slika 3).

2. Izboljšani "coning" (New York City, 1976), povezanost določil "coninga" (izraba, zazidanost, višina, obseg gradnje) in določil namenske rabe in urbanističnooblikovalskih določil (peš poti, zaščita vizur, dostopnost do postajališč javnega prometa).

3. Koristno površino okraja (floor area districts - Seattle, 1982), določitev izrabe glede na posamezne namenske rabe (stanovanje, trgovina, industrija in podobno) za določene okraje, skupaj $z$ nadzorom višin (slika 4).

Večino omenjenih kvantitativnih meril, predvsem izrabo in zazidanost, so $\mathrm{v}$ vsakdanji planerski rabi tudi pri nas (prostorski plani, PUPi), podrobneje pa so bili obravnavani v raziskavi Posledice in učinki visoke in nizke stanovanjske gradnje na stanovanjsko okolje, UI SRS, 1976 (slika 5). 


\section{Nemerljiva - kvalitativna merila}

V tem delu prispevka smo povzeli in analizirali oblikovalska merila, za katera posamezni avtorji, strokovna združenja ali lokalne planske oblasti menijo, da so pomembna za oblikovanje urbanega okolja. Zato so predlagali, da bi jih klasificirali glede na njihovo uporabnost $\mathrm{v}$ posameznih fazah procesa planiranja mesta.

Delo Kevina Lyncha, ki ga poznamo in uporabljamo tudi v naši planerski praksi, pomeni neposreclen poskus odkrivanja, kako ljudje dojemajo fizično, zlasti vizualno okolje, in se nanj odzivajo. To je tudi poskus, kako to predstaviti $\mathrm{v}$ grafični obliki, ki jo lahko uporabimo $\mathrm{v}$ planski analizi in predlogih za oblikovalske rešite. Lynch predstave o okolju analitično deli na tri komponente: identiteto, strukturo in pomen. Identiteta pomeni, da so objekti ali skupine objektov spoznavni in razvidni kot ločljiva enota (zaključenost, dominantnost, jasna členitev, diferenciranost smeri). Struktura je po Lynchu prostorsko ali modularno razmerje med objektom in okoliškimi objekti. Določen objekt pa lahko pri opazovalcu vzbuja funkcionalne/praktične, socialne, kulturne ali emocionalne pomene.

Lynch je proučeval načine, kako mesta opazovujemo, in implikacije mestne slike pri njihovem oblikovanju. Njegovo delo je usmerjeno predvsem v določanje "čitljivosti" mesta: “... lahko ta prepoznavanja in organizacije mestnih delov povezujemo $v$ koherentro celoto".

Slika 5: Primerjalna tabela urbanističnih kvantitativinih kriterijev oz. kazalcev za stanovanjsko zazidavo različnih višin

$i=i z r a b a$,

$p=$ prostornost

$g=$ gostota

$z=$ zazidanost

Vir: Šarec, L. et al: Posledice in učinki visoke in nizke gradnje na stanovanjsko okolje, UI SRS, 1976

\begin{tabular}{|c|c|c|c|c|c|c|c|}
\hline \multicolumn{8}{|c|}{ 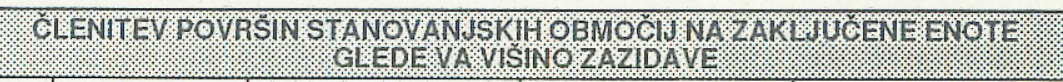 } \\
\hline \multirow[b]{2}{*}{ št. } & \multirow[b]{2}{*}{ naselje } & \multicolumn{2}{|c|}{ nizka zazidava } & \multicolumn{2}{|c|}{ srednja zazidlava } & \multicolumn{2}{|c|}{ visoka zazidava } \\
\hline & & $\operatorname{tip}_{\text {tip }}$ & $\begin{array}{c}\text { urban. } \\
\text { pokazatelji }\end{array}$ & $\operatorname{tip}_{\text {tip }}$ & $\begin{array}{l}\text { urban. } \\
\text { pokazatelji }\end{array}$ & tip & $\begin{array}{c}\text { urban. } \\
\text { pokazatelji }\end{array}$ \\
\hline 1 & Murgle & 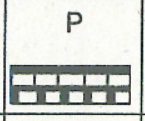 & $\begin{array}{l}i=0,23 \\
g=22 \\
p=3,4 \\
z=0,23\end{array}$ & & & & \\
\hline 2 & Komenda & 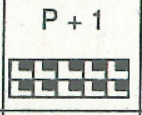 & $\begin{array}{l}i=0,20 \\
g=9 \\
p=4,25 \\
z=0,10\end{array}$ & & 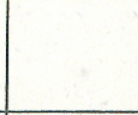 & & \\
\hline 3 & Kokrica & $\begin{array}{c}\mathrm{P}+1 \\
\mathrm{E}+\mathrm{H}+\mathrm{H} \\
\end{array}$ & $\begin{array}{l}i=0,33 \\
g=17 \\
p=2,57 \\
z=0,16\end{array}$ & & & & \\
\hline 4 & Cerklje & $\begin{array}{c}\mathrm{P}+1 \\
\mathrm{y}\end{array}$ & $\begin{array}{l}i=0,23 \\
g=22 \\
p=3,75 \\
z=0,12\end{array}$ & & & & \\
\hline 5 & Koseze & 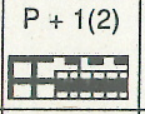 & $\begin{array}{l}i=0,24 \\
g=14 \\
p=3,6 \\
z=0,14\end{array}$ & $\begin{array}{c}P+4 \\
-10 \\
\end{array}$ & $\begin{array}{l}i=1,99 \\
g=158 \\
p=0,3 \\
z=0,38\end{array}$ & & \\
\hline 6 & $\begin{array}{l}\text { Draveljska } \\
\text { gmajna }\end{array}$ & $\begin{array}{l}\mathrm{P}+1(2) \\
\mathrm{P}\end{array}$ & $\begin{array}{l}i=0,45 \\
g=22 \\
p=1,4 \\
z=0,35\end{array}$ & $\begin{array}{c}P+4 \\
-2\end{array}$ & $\begin{array}{l}i=0,7 \\
g=98 \\
p=1,16 \\
z=0,15\end{array}$ & & \\
\hline 7 & Bakovnik & $\begin{array}{c}P+1 \\
+ \\
\end{array}$ & $\begin{array}{l}i=0,18 \\
g=14 \\
p=4,4 \\
z=0,18\end{array}$ & $\begin{array}{c}P+3 \\
8\end{array}$ & $\begin{array}{l}i=1,0 \\
g=146 \\
p=76 \\
z=0,23\end{array}$ & & \\
\hline 8 & $\begin{array}{l}\text { Cankarjevo } \\
\text { naselje }\end{array}$ & 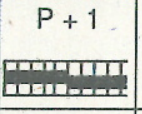 & $\begin{array}{l}i=0,36 \\
g=29 \\
p=2,2 \\
z=0,21\end{array}$ & $\begin{array}{c}P+4 \\
8=1\end{array}$ & $\begin{array}{l}i=1,09 \\
g=151 \\
p=0,7 \\
z=0,25\end{array}$ & $\begin{array}{l}P+10 \\
=\end{array}$ & $\begin{array}{l}i=1,26 \\
g=186 \\
p=0,6 \\
z=0,13\end{array}$ \\
\hline 9 & $\begin{array}{l}\text { Štepanjsko } \\
\text { naselje }\end{array}$ & 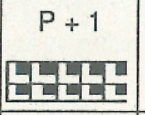 & $\begin{array}{l}i=0,25 \\
g=14 \\
p=3,2 \\
z=0,13\end{array}$ & $\begin{array}{c}P+4 \\
\square \square\end{array}$ & $\begin{array}{l}i=0,8 \\
g=104 \\
p=1,0 \\
z=0,17\end{array}$ & $\begin{array}{l}P+13 \\
- \\
\end{array}$ & $\begin{array}{l}i=1,8 \\
g=235 \\
p=0,5 \\
z=0,13\end{array}$ \\
\hline 10 & $\begin{array}{l}\text { BS-7 } \\
\text { Ljubljana }\end{array}$ & $*$ & $*$ & $*$ & * & $\begin{array}{l}P+7 \\
=\square\end{array}$ & $\begin{array}{l}i=1,25 \\
g=156 \\
p=0,69 \\
z=0,14\end{array}$ \\
\hline 11 & VS-4 Vič & & & $\begin{array}{lll} & P+4 \\
& & \\
\text { a) } & \text { b) }\end{array}$ & $\begin{array}{l}\text { a) } \\
i=0,76 \\
p=1,15 \\
g=109 \\
z=0,13 \\
b) \\
i=0,94 \\
p=0,86 \\
g=156 \\
z=0,18\end{array}$ & & \\
\hline 12 & Stožice BS-3 & & & 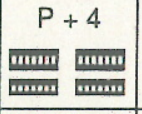 & $\begin{array}{l}i=0,85 \\
g=106 \\
p=1,0 \\
z=0,14\end{array}$ & $\begin{array}{c}P+16 \\
=\end{array}$ & $\begin{array}{l}i=1,4 \\
g=2,14 \\
p=0,65 \\
z=0,09\end{array}$ \\
\hline 13 & $\begin{array}{l}\text { Šs-6 } \\
\text { Ljubljana }\end{array}$ & & & $P+3$ & $\begin{array}{l}i=0,51 \\
g=86 \\
p=1,7 \\
z=0,13\end{array}$ & $P+10$ & $\begin{array}{l}i=1,68 \\
g=238 \\
p=0,48 \\
z=0,19\end{array}$ \\
\hline 14 & Planina & & & * & $*$ & $\begin{array}{c}P+6 \\
-1 T \backslash\end{array}$ & $\begin{array}{l}i=1,14 \\
g=127 \\
p=0,7 \\
z=0,21\end{array}$ \\
\hline 15 & Trnovo & & & * & * & $\begin{array}{c}P+6 \\
=\end{array}$ & $\begin{array}{l}i=1,4 \\
g=175 \\
p=0,56 \\
z=0,23\end{array}$ \\
\hline 16 & Šs- $8 / 2$ in $7 / 1$ & & & & & $\begin{array}{c}P+11 \\
=-\end{array}$ & $\begin{array}{l}i=1,5 \\
g=185 \\
p=0,6 \\
z=0,2\end{array}$ \\
\hline 17 & Ferantov vrt & & & & & $\begin{array}{c}P+7 \\
\square\end{array}$ & $\begin{array}{l}\mathrm{i}=3,8 \\
\mathrm{~g}=365 \\
\mathrm{p}=0,12 \\
\mathrm{z}=0,46\end{array}$ \\
\hline
\end{tabular}


Za Lyncha so pomembni elementi mestne podobe ali slike mesta: orientacija, lahkota gibanja in enostavno odkritje želene poti. Pri raziskovanju uporabnikove percepcije mesta v zvezi z "branjem mesta oziroma mestne slike" določa pet ključnih elementov: poti (koridorji gibanja - ulice, aleje, avtoceste), vozlišča (fokalne točke aktivnosti - križišča, trgi), znamenja (simbolne točke spomeniki), robovi (vizualne meje Železniški viadukti, reke, kanali) in kvarti (urbana območja $z$ identificiranimi skupnimi značilnostmi značilna območja mestnega tkiva). Čitljivost je odvisna od razmerja med omenjenimi elementi in je eno od pomembnih urbanističnooblikovalskih meril, ki ga uporabljamo, "da označimo prostore, ki so zasnovani tako, da so lahko razumljivi za uporabnike oziroma da jih uporabniki hitro obvladlajo" (Bentley in Butina, 1990).

Lynch je kasneje razvil bolj poglobljeno ogrodje "normativistične teorije mestnih form", in sicer $z$ vrsto kvalitativnih meril, ki je, kot bomo videli pozneje, pomembno za nadzor pri oblikovanju planskega razvoja:

- dostopnost (access, možnost doseganja drugih aktivnosti, virov ali prostorov, skupaj $z$ raznolikostjo elementov, ki so dosegljivi),

- prilagodljivost (fit, stopnja, do katere oblike in climenzije/kapacitete prostorov, oprema $v$ naselju zadovoljujejo vzorce in kvantiteto uporabe prebivalcev),

- pomen (sense, stopnja, do katere prebivalci lahko jasno dojemajo zasnovo naselja in ga mentalno diferencirajo in strukturirajo $\mathrm{v}$ času in prostoru, in stopnja, do katere se ta mentalna struktura naselja navezuje na njihovo konceptualno predstavo o vrednosti okolja),

- vitalnost/aktivnost (livability, stopnja, do katere naselbinske oblike dopolnjujejo vitalne funkcije, biološke potrebe in sposobnosti človeška) in

- nadzor vitalnosti (control vitality, stopnja dostopnosti in uporabe prostorov in objektov ter možnosti nadzora pri oblikovanju, spremembah in upravljanju kar zadeva uporabnike).
Lynchove predloge za kvalitativna merila so povzeli in dopolnili $\mathrm{v}$ številnih urbanističnooblikovalskih pristopih glede urejanja mesta (npr. behaviouristični, razvojni - gl. Dimitrovska, 1989; Bentley, 1985) kot tudi v vsakdanji planerski praksi.

Pregled uporabe posameznih oblikovalskih meril $\mathrm{v}$ planskih dokumentih v ZDA v obdobju 1960-1987 na primer je pokazal, da so najbolj zastopana naslednja merila:

- čitljivost strukture (pomen prostora, pogledi, kontinuiteta ulične podobe),

- identiteta oblike (humano merilo, vizualna kvaliteta),

- vitalnost ("Živahnost" ulic),

- dostopnost (enaka dostopnost za vse),

- različnost (mešane rabe prostora) (Punter, 1992).

Podobno opredeljujeta uporabo oblikovalskih meril pri' raziskovalnem delu in v vsakdanji praksi tudi Shirvani (1985, str.126) in Bentley (1985), kot najbolj zastopane pa navajata:

- dostopnost,

- različnost (vitalnost, primernost za bivanje - livability),

- čitljivost,

- prilagodljivost,

- vizualna primernost in

- vizualni interes (vizualno bogatstvo, pestrost).

Temeljna načela in merila dobrega urbanističnega oblikovanja so na osnovi Lynchevega dela poskušale opredeliti tudi lokalne oblasti. Načrt za San Francisco (ZDA) je uspešen zgled takega pristopa, ki vključuje deset temeljnih principov za doseganje urbanistično oblikovalskih kvalitet pri razvoju mesta (povzeto po Shirvaniju, 1985, str.122-123). Naj jih podrobneje opišemo:

1. ugodje, skrb za pešca (primerno oblikovanje cest, primerne zasaditve in udobna cestna oprema, zaščita pred dežjem in podobno);

2. vizualni interes, estetske kvalitete okolja (arhitekturni značaj in vizualno prijetni detajli);

3. aktivnost, pomembnost "življenja na cesti" (nepretrgani trgovski programi v pritličjih objektov, Živahni javni prostori); 
4. jasnost orientacije in primernost, dostopnost za pešce (olajšanje peščevega doživljanja urbanega okolja);

5. raznolikost urbanega okolja, identiteta in individualnost $\mathrm{v}$ oblikovanju posameznih urbanih struktur in prostorov;

6. pomembnost razmerja polnoprazno v urbanem okviru, pojavnost in razmerje odprtih javnih prostorov do grajenega obrobja (merila pojavnosti: pogledi, značaj in dostopnost);

7. pomembnost principa "pravica pogleda" in "ugodje pogleda" ter percepcijski aspekti orientacije v urbanem okolju (zasnova ulic, postavitev objektov in odnos njihovih mas kot kritične komponente pri opredelitvi estetskega značaja in vizualne dostopnosti);

8. različnost/kontrast arhitekturnih elementov (stil, kompozicija) kot merilo iclentifikacije soseščine in interesnih lokacij znotraj lokalne skupnosti;

9. harmoničnost/kompatibilnost objektov in prostorov: arhitekturni in estetski aspekti razmerja objektov do topografije (tudi med seboj) v skladu s prehodi, komplementarnostjo $\mathrm{v}$ merilu in zasnovi mas;

10. pomembnost merila in vzorca za doseganje humanega urbanega okolja (upoštevanje velikosti, gabarita, razmerja mas med posameznimi objekti, estetske dimenzije kontekstualne senzitivnosti in strukturalnega efekta pri grajenem merilu v dolgih pogledih).

Lynchevi predlogi kvalitativnih meril so bila upoštevana kot merila, pomembna za oblikovanje celostne podobe naselja, tudi v raziskavi Urbanistični merila za urejanje prostora v SRS (1977, str. 167-178), kjer je za oblikovanje celostne podobe urbanih prostorskih struktur opredeljenih devet glavnih meril:

dostopnost, zadovoljivost mestnih funkcij, kongruentnost/skladnost sistema, raznolikost, prilagodljivost, čitljivost, varnost, stres/napetost, učinkovitost samega mestnega sistema. Ta merila so $\mathrm{z}$ viclika oblikovanja mesta še vedno pomembna. Kljub temu pa bo treba podrobneje proučiti njihovo uporabo na posameznih ravneh planiranja in urejanja mestnega prostora.

Predhodna analiza in primerjava oblikovalskih meril in principov, ki jih omenjajo različni avtorji (npr. Lynch, 1981; Cullen, 1971; Bentley et al, 1984; Buchanan, 1988; Youngson, 1990 idr.) uporabljali pa so jih v vsakdanji planerski praksi, je pokazala, da se le-ti nanašajo na tri osnovne kategorije, ki nanje vplivajo in jih določajo:

1. kontekst in splošno kompatibilnost fizičnih struktur,

2. zasnovo in zunanjo učinkovitost njihove kompozicije in

3. arhitekturno oblikovanje grajenih form (gl. slika 6 Oblikovalska merila in fizične strukture).

Naš predlog zasnove klasifikacije (Dimitrovska, 1993) je pomemben zlasti zato, ker je skladen s posameznimi ravnmi planiranja in načrtovanja mesta. Tako je upoštevanje meril v zvezi $z$ kategorijo 1 pomembno za mestno raven planiranja, ker pomeni integracijo določenega razvoja lokacije skladno s funkcionalno zasnovo mesta kot celote, in je $\mathrm{v}$ skladu $\mathrm{z}$ enotno strategijo pri razvoju mestne podobe. Merila $v$ zvezi $z$ kategorijo 2 določajo zasnovo zazidave na ravni lokacijskega načrtovanja, pomembni pa so za usklajen razvoj mikroambientov, kot tudi za urejanje neposrednih stikov in povezav/ navezav $s$ sosednjimi objekti in programi v soseščini. Merila v zvezi $z$ kategorijo 3 se nanašajo na arhitekturno zasnovo in oblikovanje objektov, z izjemo oblikovalskih usmeritev za izrazito pomembne lokacije (npr. tiste, ki so identificirane v strategiji oblikovanja mesta), ali usmeritev, ki izhajajo iz zasnove oblikovanja določenega mestnega območja ali mestne četrti (npr. prevladujoči arhitektumini stil, gradbeni materiali in podobno), pa so izključno domena arhitektov in načrtov $v$ arhitekturi. 


\section{Kontekst in splošna kompatibilnost (oblikovanje glede na širši mestni prostor)}

Kontekst, zazidava v kontekstu, ohranjanje in razvijanje urbane in arhitekturne kontinuitete so pomembna planska določila, ki usmerjajo oblikovanje fizičnih struktur skladno z značilnostimi lokacije (topografija, krajina, mestna podoba, mestna silhueta in vizure), namenske rabe in merila prostora. Osnovne značilnosti in kvalitete tradicionalnega mesta so $\mathrm{v}$ razpoznavnem urbanem vzorcu in $\mathrm{v}$ kompleksnosti znotraj razpoznavnega reda, zato je pri načrtovanju izgradnje ali prenove določene lokacije treba upoštevati kontekst prostora, ki vključuje zgodovinski razvoj, dejansko podobo in pomen, planski status ter socialno in ekonomsko vlogo (dejansko in možno).

Merila, ki so pomembna $z$ vidika kontekstualnega oblikovanja danega območja in izhajajo iz oblikovne podobe mesta kot celote, so skladnost in kompatibilnost, vizualno ugodje, princip/pravica pogledov, vidni vplivi preteklosti (v dialogu s kontekstom in zgodovino), pomen prostora, raznolikost ter humano merilo, nanašajo pa se na:

\section{1okacijo}

upoštevanje topografsko-krajinskih značilnosti in varovanje pogledov na najpomembnejše naravne dominante in panoramske razglede, upoštevanje značilnosti urbano-morfološke zgradbe mestnega območja (urbani vzorec, tematske in netematske strukture) - upoštevanje značaja lokacije $v$ strategiji razvoja mestne podobe oziroma njen pomen $\mathrm{v}$ podobi in silhueti mesta (varovanje značilne silhuete mesta, pomembnih vedut);

\section{2. program in aktivnost} kompatibilnost programov - maksimizacija raznolikosti programov in aktivnosti;

\section{3. merila}

upoštevanje karakterističnega merila lokacije (mase in gabariti), razen pri lokacijah, ki imajo značaj mestnih ali lokalnih znamenj.
Pomembnejša oblikovalska merila v tej kategoriji so skladnost, arhitekturni in esteski aspekti komplementarnosti merila, razporeditev mas ter razmerja med topografijo in grajenimi formami; kompatibilnost merilo in vzorec oziroma velikost, gabarit in organizacija gradbenih mas pri objektih ter njihova senzualna kontekstualnost $\mathrm{v}$ percepciji dolgih pogledov; princip pogledov, upoštevanje estetskega vtisa, ki ga dajejo "lepi pogledi", kot percepcijski aspekt človeške orientacije, ki se nanaša na zasnovo ulic, postavitev objektov in njihovih gradbenih mas (vedute), ki so kritične komponente estetskega značaja in vizualne dostopnosti grajenega okolja; očitni vplivi preteklosti - obstoj objektov in ambientov iz kulturne in zgodovinske dediščine kot pomemben element stabilnosti, domačnosti in prijetnosti mestnih prostorov; pomen prostora - stopnja, do katere prebivalci lahko jasno dojemajo zasnovo naselja in ga mentalno diferencirajo in strukturirajo $\mathrm{v}$ času in prostoru, in stopnja, do katere se ta mentalna struktura naselja navezuje na njihovo konceptualno predstavo o vrednosti okolja; raznolikost - različne dejavnosti ali mešani programi in aktivnosti kot predpogoj za raznoliko obliko fizičnih form in vitalnost urbanega okolja; humano merilo - humano urbano okolje, upoštevanje velikosti, gabaritov, razmerij volumnov med posameznimi objekti, kot tudi estetsko dimenzijo kontekstualne senzitivnosti in strukturalni učinek grajenega merila $\mathrm{v}$ dolgih pogledih; hierarhijo urbanih meril (domače, humano, duhovno-monumentalno, glej Dimitrovska, 1993, str. 84-85).

Kontekst ali zazidava v kontekstu je pomembno določilo $\mathrm{v}$ usmeritvah o oblikovanju fizičnih form $v$ planskih dokumentih in tudi pomemben aspekt planskega nadzora pri razvoju. Ključna terminologija, uporabljena $\mathrm{V}$ besednjaku planskega nadzora, da ponazori kontekst zazidlave oziroma odnos objekta do okolja, ki ga obdaja, zajema te besedne zveze: "ohraniti karakter", "preprečiti nasilje nad okoljem", "preprečiti tuje vsiljevanje" (Circular, 1933); "objekti naj bodo oblikovani skladno in sorodno s kon- 


\begin{tabular}{|c|c|}
\hline principi / kvalitativni kriteriji & elementi / aspekti proučevanja \\
\hline $\begin{array}{l}\text { prilagodljivost, aktivnost (Lynch); } \\
\text { primerne aktivnosti (Jacobs); } \\
\text { skladnost, kontekst, merilo v kontekstu (HRH The Prince of } \\
\text { Wales); } \\
\text { odzivajoče se okolje, raznovrstnost programov, humano merilo } \\
\text { (Bentley et al .); } \\
\text { spoštovanje zgodovine, mešani programi, merilo grajenega } \\
\text { prostora (Tibbalds); } \\
\text { ohranjanje najboljšega, več kot ena raba (Holyoak); } \\
\text { prepoznavne oblike, mešana raba (UD Group); } \\
\text { dialog s kontekstom in zgodovino (Buchanan) } \\
\text { skladnost in spodobnost, vidna prisotnost preteklosti (Youngson). }\end{array}$ & $\begin{array}{l}\text { značilnosti lokacije } \\
\text { topografija, pokrajina, mestna podoba, mestha silhueta in } \\
\text { vedute, ekološke značilnosti } \\
\text { značilnosti namenske rabe } \\
\text { mešani programi, kompatibilni programi } \\
\text { merilo } \\
\text { višina, gabarit, volumen, grupiranje mas }\end{array}$ \\
\hline
\end{tabular}

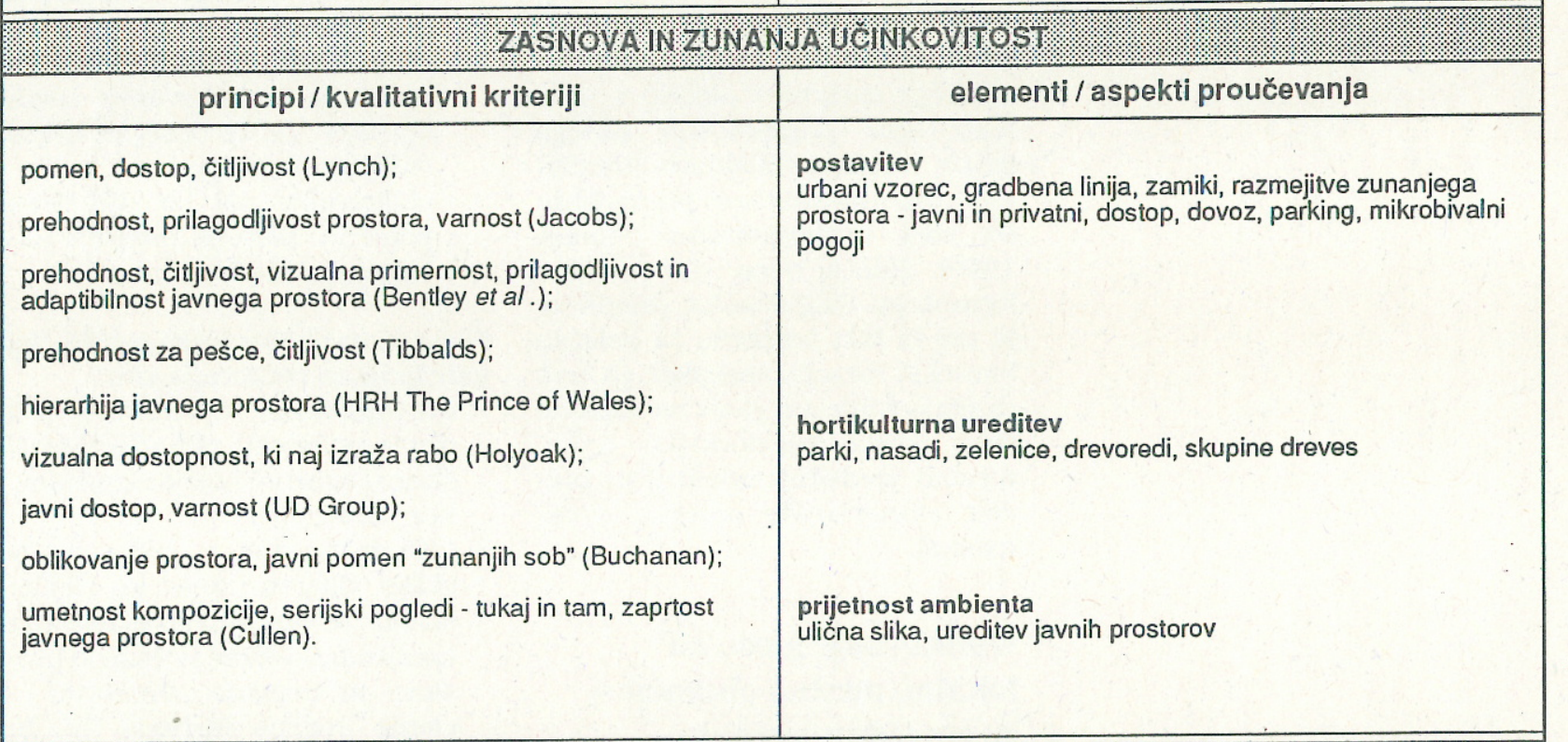

\begin{tabular}{|c|c|}
\hline \multicolumn{2}{|c|}{ MRHILKURNO OBMIKOVANL } \\
\hline principi / kvalitativni kriteriji & elementi / aspekti proučevanja \\
\hline
\end{tabular}

prilagodljivost, fleksibilnost, vizualno in simbolično bogastvo (Bentley et al.)

vizualno zadovoljstvo (Tibbalds);

materiali in dekoracija, oznake in svetila (HRH The Prince of Wales);

vidna konstrukcija, integriran ornament (Holyoak);

stimulacija, zaščita, ugodje (UD Group);

spoštovati arhitekturne konvencije, artikulirati pomen, navezati notranjost in zunanjost, uporabljati naravne materiale in dekoracijo (Buchanan). arhitekturni stil

zgodovinska referenca, pomen, simbolizem

fasade in detajli

členitev, ritem, proporce, polno-prazno, dekoracija

materiali

vrsta, barve, tekstura, kontrast, transparentnost, odpornost,

trajnost

Slika 6: Oblikovalska merila in fizične strukture 


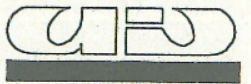

št. 26, 27/1994

tekstom" (Urban Design Plan of San Francisco, 1970); “ohranja in razvija naj se urbana in arhitekturna kontinuiteta" (Zakon o urejanju naselij, 1984, čl.9), "oblikovalski pogoji naj upoštevajo koncept stare tlorisne zasnove naselja in lokalne tradicije oblikovanja stavbnih mas, uporabe arhitektonskih prvin ter obdelave fasad in uporabe materialov" (Navodilo o vsebini posebnih strokovnih podlag in o vsebini prostorskih izvedbenih aktov, 1985, čl.15). Tudi novejše razprave o estetskem nadzoru v strokovnih krogih (RIBA Conference, 1992) poudarjajo potrebe po boljši prezentaciji vlog za lokacijske dokumentacije, ki naj bi vsebovale analizo in ilustracijo kontekstualne dimenzije za predlagano gradnjo oziroma ureditve.

Tu je treba upozoriti, da formalistično, nekritično izvajanje oblikovalskega nadzora $v$ skladu s kontekstualno primernostjo posega lahko zaduši arhitektovo kreativnost, ovira inovativnost pri projektu ter vodi $\mathrm{V}$ plagiatorstvo (Punter, 1990). Zato je treba zelo previdno formulirati oblikovalska izhodišča, ki naj bi bila primerna za določen kontekst razvoja, vsekakor pa tudi različno zahtevna glede na različne dele mesta (zgodovinsko jedro, mestno središče, industrijski predeli, stanovanjske soseske, predmestja).

\section{Oblikovanje gledle na lokalno mestno območje - neposredno soseščino}

\section{Zasnova in zunanja učinkovitost}

Pri zasnovi zazidave oziroma ureditvi moramo spoštovati lokalni pomen prostora. Mestni prostori morajo imeti vizualno identiteto, biti morajo prepoznavni in zapomljivi. S planskega vidika so najbolj pomembni: prehodnost in jasnost orientacije $\mathrm{v}$ prostoru, izrazitost osnovne funkcije, vizualno poudarjeni javni prostori in družbene institucije, ekspozicija naravnih in grajenih značilnosti prostora.

Oblikovalska merila, ki so pomembni za doseganje pomena prostora in preclvsem kvalitete javnega po- mena, so: dostopnost, prehodnost, čitljivost, vizualna primernost in prilagodljivost, nanašajo pa se na:

\section{1. postavitev objektov}

- maksimizacija dostopnosti in prehodnosti območja,

- vključitev lokalnih značilnosti v predvidene zazidave oziroma ureditve in

- upoštevanje lokalnega besednjaka urbanih form (ulični profili in prerezi, gradbene linije, višine in členitev objektov);

\section{2. hortikulturno ureditev}

- upoštevanje zasnove zelenega sistema mesta,

- uporaba avtohtonega zelenja;

\section{3. ambient}

- zagotavljanje prijetnosti javnih prostorov,

- upoštevanje kontekstualnega načela pri oblikovanju novih objektov, da bi closegali boljšo čitljivost območja,

- oblikovanje naj bo podrejeno pomenti lokacije nasproti celostni podobi mesta.

Posamezna oblikovalska merila v tej kategorije so definirana kot:

- dostopnost - možnost doseči druge aktivnosti, vire ali prostore, skupaj $z$ raznolikostjo elementov, ki so dosegljivi;

- čitljivost - čutna oblika, ki je vidno diferencirana in zlahka strukturirana, oblika, ki ustvarja kontinuirani vzorec $v$ času in prostoru in ustvarja učinkovito celotno podobo (Kriteriji UISRS, 1977);

- kvaliteta oblikovanja prostorov, ki so zasnovani tako, da so lahko razumljivi uporabnikom oziroma da jih uporabniki hitro obvladajo (Bentley in Butina, 1990). Citljivost se lahko nanaša na oblikovanje objektov skladno s kontekstualnim načelom oblikovanja, kar pomeni upoštevanje značilnih ritmov členitve fasad in fasadnih odprtin, tipične zaključke strešin, značilne detajle oblikovanja pritličnega prostora in uporabe materialov;

- vizualna primernost - stopnja, do katere detajlni izgled prostora omogoča, da se uporabniki zavedajo vseh možnih izbir $\mathrm{v}$ tem 
prostoru. Vizualna primernost urbanih ambientov je odvisna od čitljivosti, raznolikosti in prilagodljivosti objektov in prostorov;

- prilagodljivost je stopnja, do katere oblike in dimenzije/kapacitete prostorov in opreme $v$ naselju zadovoljujejo vzorce in frekvenco/količino uporabe prebivalcev;

- vitalnost/aktivnost - stopnja, do katere naselbinske oblike dopolnjujejo vitalne funkcije, biološke potrebe in sposobnosti človeka.

Tu lahko naštejemo tudi kvalitativna merila, ki so bila določena $v$ nekaterih planskih dokumentih, kot so:

- jasnost in primernost - karakteristike, ki poenostavljajo peščevo izkušnjo, orientacijo in uporabo urbnanega okolja, značilnost/posebnost identiteta struktur in urbanih prostorov (Urban Design Plan of San Francisco, 1970) in

- dostopnost in orientacija - jasnost in varnost oblikovanja ciljnih poti, prikaz identitete - socialna in funkcionalna pomembnost vizualne podobe $\mathrm{V}$ zvezi $\mathrm{Z}$ identiteto in statusom za uporabnike in za lokalno skupnost (Urban System Research and Engineering, 1977).

Ta kategorija urbanističnooblikovalskih meril je pomembna za doseganje vrednot javnega pomena. Vse temeljne oblikovalske usmeritve $\mathrm{v}$ tej kategoriji so pomembne za izkušnje uporabnika urbanega prostora, kajti iz njih tucli izhajajo. Vloga kategorij, kot so dostopnost, varnost, udobje in ustreznost, je včasih bolj pomembna kot arhitekturno zadovoljstvo in navdušenje (Punter, 1990).

\section{Arhitekturno oblikovanje}

Nadzor pri arhitekturnem oblikovanju je opravičljiv samo za cloločene lokacije, kot so lokacije v zvezi $z$ prenovo ali bolj občutujive lokacije mestnega tkiva, ki bi morale biti $v$ planskih dokumentih opredeljene s podrobnejšimi uismeritvami (npr. $\mathrm{V}$ oblikovalski strategiji mesta).

Oblikovalska merila, ki so pomembna za doseganje vizualnega reda, enotnosti in kontinuitete $\mathrm{V}$ oblikovanju, so spoštovanje arhitekturnih stilov/kompozicije, artikulirani pomen, vizualno in simbolno izročilo, obstojnost in trajnost, nanašajo pa se na:

\section{1. arhitekturni stil}

- upoštevanje značilnosti arhitekturne krajine,

- upoštevanje sintaktičnega, semantičnega in pragmatičnega pomena objekta $\mathrm{v}$ urbani zasnovi;

\section{2. fasade in detajle}

- upoštevanje kontekstualnih značilnosti območja,

- upoštevanje intenzitete vizualne ekspozicije objektov;

\section{3. materiale}

- upoštevanje kontekstualne uporabnosti,

- upoštevanje trajnosti in enostavnosti vzdrževanja.

Podobna kvalitativna merila pri arhitekturnem oblikovanju $\mathrm{V}$ urbanem okolju zahtevajo tudi planski dokumenti, na primer: vizualni interes-izražen arhitekturni karakter in vizualno privabljivi detajli, različnost in kontrast $\mathrm{v}$ arhitekturi, pomembnost arhitekturnega stila in kompozicije (Urban Design Plan of San Francisco, 1970). Ta merila so zajeta tudi v zakonodaji: "ohranjati tipologijo regionalne arhitekture" (Zakon o urejanju naselij, 1984, čl.9), "oblikovalski pogoji naj upoštevajo uporabo lokalnih arhitekturnih prvin ter obdelavo fasad in uporabo materialov" (Navodilo o vsebini posebnih strokovnih podlag in o vsebini prostorskih izvedbenih aktov, 1985, čl.15).

Arhitekturno vprašanje je gotovo najbolj občutljivo področje pri nadzoru oblikovanja urbanega prostora. Poročilo Planiranje za lepoto, ki ga je leta 1985 izdelala Kraljeva komisije za lepe umetnosti v Angliji, $v$ razpravi o vizualnem učinku grajenih form določa, da je le-ta rezultat estetskega vtisa glede razmerja polno-prazno, razporeditve in oblikovanja odprtin, vertikalnega ali horizontalnega poudarka kompozicije, barve in teksture, modeliranja in dekoracije. Aspekti, ki bi jih bilo smiselno upoštevati $\mathrm{v}$ procesu ar- 
hitekturnega oblikovanja (gl. tabelarični prikaz), in ki so pomembni tudi $z$ vidika konteksta, vključujejo: arhitekturni stil (zgodovinska referenca, pomen, simbolizem), fasade in detajle (členitev, ritem, proporci, odnos polno-prazno, dekoracija) in materiale (vista, barve, tekstura, kontrast, transparentnost, odpornost, trajnost).

Obravnava oziroma preokupacija $z$ arhitekturnim stilom, ki je zelo pogosta $v$ praksi pri britanskih kritikih urbanizma oziroma mestne podobe, pa tudi pri planerjih, ki se ukvarjajo $\mathrm{Z}$ estetskim nadzorovanjem, se je izkazala kot velika napaka (Punter, 1985; Larkham, 1988). Tako se neoklasicistični, neogeorgijanski in neovernakularni stili povsed pojavljajo, ne da bi jih kritično uporabljali. Končni učinek v urbanem okolju je zato še manjši od tistega, ki naj bi mu nasprotovali (Punter, 1990). Tako je nekritično poudarjanje neovernakularnega stila, ki so ga uveljavljali planerji $\mathrm{v}$ zahodni in centralni Angliji prispevalo k temu, da ima na tem območju približno $80 \%$ stanovanjskih hiš, zgrajenih po letu 1970, podoben stil, kar se izraža v dolgočasnem okolju, stereotipnem ponavljanju enakih urbanih vzorcev in enake tipologije objektov (Larkham, 1988).

Kaj naj, potemtakem, vsebujejo oblikovalske usmeritve, da bi lahko zagotavljale kontinuiteto pri oblikovanju urbanega prostora, čeprav dopuščajo arhitektu svobodo, s katero naj bi izrazil svojo popolno ustvarjalnost? Nekatera oblikovalska načela, ki jih definira Buchanan (Youngson, 1990), se zdijo še najbolj primerna:

- izrazitost in hierarhičnost pri oblikovanju prostora, ki ga določajo fasade objektov (podrejenost fasad oblikovanju zunanjega, javnega prostora - "zunanje sobe");

- obveznost, da pri oblikovanju fasad upoštevajo arhitekturna pravila, da zadovoljujejo potrebo po vizualni in simbolni izrazitosti, da uporabljajo naravne materiale, ki so bolj odporni, in da upoštevajo pomembnost dekoracije, ki naj vznemirja in navdušuje, intrigira in sporoča.

\section{Povzetek}

Pregled urbanistično oblikovalskih elementov $\mathrm{v}$ veljavni zakonodaji $\mathrm{v}$ zvezi $\mathrm{z}$ prostorskim plàniranjem in načrtovanjem $v$ Sloveniji je pokazal njihovo izredno zastopanost, ki pa, glede na ugotovitve strokovnjakov (Razmišljanja o Ljubljani, IS mesta Ljubljane, 1991), večinoma ni uspela udejaniti estetskega okolja. Za to je gotovo veliko vzrokov (od političnih do ekonomskih), med njimi sta tudi slabo razumevanje zakonskih določil in nestrokovnost načrtovalcev. Pri pripravi nove prostorske zakonodaje bi najprej morali osvetliti oziroma podrobneje določiti vplive oblikovalskih meril na razvoj fizičnih struktur in ugotoviti, katere elemente razvoja fizičnih struktur bi morali $z$ vidika varovanja podobe mesta in posameznih vrednot lokalnega urbanega okolja usmerjati in nadzorovati.

Glede na to smo $\mathrm{v}$ tem prispevku opredelili osnovna urbanističnooblikovalske merila, ki so pomemebna za estetski razvoj mesta, poleg tega smo jih poskusili razvrstiti tudi glede na njihov značaj, ki ga imajo na posameznih ravneh planiranja (splošnega in lokalnega), ter na zahtevnost posamezne lokacije (od nadzora pri urbanistični zasnovi do arhitekturnega detajla). Mnoga od naštetih oblikovalskih meril (npr. čitljivost, enotnost in različnost, skladnost in kompatibilnost, kompleksnost in red), so pomembna tako za splošno kakor tudi za lokalno urbano kompozicijo, pa tudi za arhitekturno oblikovanje samega objekta.

Zato smo tudi predlagali pripravo priročnika za oblikovanje urbanih prostorov (oziroma za potrebe urbanističnih oblikovalcev), ki bi tekstualno in grafično ponazoril vpliv teh meril na razvoj fizičnih struktur mesta glede na že opredeljene tri osnovne kategorije: kontekst in splošna kompatibilnost, zasnova in zunanja učinkovitost ter arhitekturno oblikovanje. Ugotovili smo namreč, da so te kategorije primerljive oziroma značilne za posamezne ravni planiranja ter hierarhično stopnjevanje zahtevnosti pri izvajanju nadzora v oblikovanju. Posa- 
mezne elemente teh kategorij je treba predstaviti $z$ oblikovalskimi merila urejanja, razložiti njihove značilnosti in povzeti ( $\mathrm{v}$ obliki priporočil) vidike, ki so pomembni za planiranje/načrtovanje in izvajanje nadzora pri oblikovanju. Tako zasnovan priročnik bi imel tudi poučno/izobraževalno vlogo in bi bil za upravne ter planerske službe koristen pripomoček, ker je, kot smo ugotovili, kvalitativna merila težko nadzorovati brez predhodnega osnovnega znanja o urbanističnem oblikovanju oziroma o principih dobrega oblikovanja.

Dr. Kaliopa Dimitrovska Andrews, dipl, inž arh., direktorica UI RS

\section{Literatura}

Bentley, I. et al: Responsive Environment, A manual for designers. The Architectural Press Ltd. London 1985.

Bentley, I., Butina, G.: Urban Design Key words and phrases. The Architects Journal, No. 17, Volume 192, 1990.

Braunfels, W.: Urban Design in Western Europe, Regime and Architecture, 9001900. The University of Chicago Press, London 1988.

Cullen, G.: The Concise Townscape. Van Nostrand Reinhold, New York 1971.

Cullingworth, J. B.: Town and Country Planning in Britain. George Allen \& Unwin, London 1982.

DeChiara, J., Koppelman, L.: Urban Planning and Design Criteria. Van Nostran Reinhold Company, New York 1982.

Dimitrovska, K.: Morfološka analiza razvoja mest $v$ južnem delu Jugoslavije $z$ aplikacijo na primeru Titograda (magistrska naloga). IPŠPUP, FAGG, Univerza Edvarda Kardelja v Ljubljani, Ljubljana 1989.

Dimitrovska, K.: Elementi estetske kontrole $\mathrm{v}$ sistemu planiranja in urejanja prostora. Republika Slovenija, Ministrstvo za varstvo okolja in urejanje prostora, Zavod RS za prostorsko planiranje. Ljubljana 1993.

Hayward, R., McGlynn, S.: Making Better Places - Urban Design Now. Joint Centre for Urban Design, Butterworth Architecture, Oxford 1993.

Lang, J.: Creating Architectural Theory, The Role of Behavioral Sciences in Environmental Design. Van Nostrand Reinhold Company, New York 1987.

Lynch, K.: Slika jednog grada. Gradevinska knjiga, Beograd 1981.
Lynch, K.: City Sense and City Design, Writings and projects of Kevin Lynch, The MIT Press, Cambridge, Massachusetts 1990.

Ogorelec, B.: Urbanistični predpisi, prispevek k študiju normativnega urbanizma. Urbanistični inštitut RS, Ljubljana 1991.

Planning Control, HMSO, 1989.

Prelovšek, A.: Minimalna urbanistična regulacija (magistrsko delo). IPŠPUP, FAGG, Univerza Edvarda Kardelja v Ljubljana, Ljubljana 1988.

Punter, J.: The Ten Commandments of Architecture and Urban Design. The Planner, No. 39, 1990.

Ravetz, A.: The Government of Space, Town Planning in Modern Society. Faber and Faber, Londion-Boston 1986.

Souvan, T., Ogorelec, B. ed.: Razmišljanja o Ljubljani, Mesto Ljubljana, Ljubljana 1991.

Shirvani, H.: The Urban Design Process. Van Nostran Reinhold Company, New York 1985.

Smith, P. F.: Architecture and the Principles of Harmony. RIBA Publications Lid.. London 1987.

Šarec, L.: Posledice in učinki visoke in nizke gradnje na stanovanjsko okolje, zv. 1 in 2. Urbanistični inštitut SRS, Ljubljana 1976.

Šarec, L. et al.: Urbanistični kriteriji za urejanje prostora v SRS, zv. 1-6, Urbanistični inštitut SRS, Ljubljana 1977 (1980).

Teymur, N.: "Aesthetics" of Aesthetics, Aesthetic questions in architectural and urban discourses, 1981.

Tibbalds, F.: Making People-Friendly Towns, Improving the Public Environment in Towns and Cities. Longman Group UK Ltd, London 1992.

Youngson, A. J.: Urban Development and the Royal Fine Arts Commissions. Edinburgh University Press, Edinburgh 1990.

\section{Zakoni in predpisi}

Department of the Environment: Draft Circular on Good Design and Developmental Control, 1983

Gradbeni zakon in gradbeni pravilnik, 1931.

Predlog zakona o urejanju prostora in graditvi, 9. verzija, november 1993.

Zakon o graditvi objektov, UL SRS, 34/ 1984 in 29/1986.

Zakon o stavbnih zemljiščih, UL SRS, $18 / 1984$.

Zakon o urejanju prostora, UL SRS, 18/ 1984.

Zakon o urejanju naselij in drugih posegov v prostor, UL SRS, 18/1984. 